\section{In Vitro Propagation of Citrus reticulata Blanco and Citrus limon Burm.f.}

\author{
S. Singh, B.K. Ray, S. Bhattacharyya, and P.C. Deka \\ Agricultural Biotechnology Programme, Assam Agricultural University, \\ Jorhat- 785013, Assam, India
}

Additional index words. Citrus reticulate, Citrus limon, shoot-tip culture, micropropagation

Abstract. Multiple shoots were obtained from shoot tips ( 2 to $3 \mathrm{~mm}$ ) derived from mature plants (5 to 6 years old) of Citrus reticulata Blanco Cv. Khasi mandarin and C. limon Burm.f. CV. Assam lemon when cultured on Murashige and Skoog (MS) medium, supplemented with $\left(\mathrm{mg} \cdot \mathrm{liter}^{-1}\right)$ 1.0 BAP, 0.5 kinetin, and 0.5 NAA. Root induction was observed when 7 -week-old single shoots $(\approx 2 \mathrm{~cm}$ long) of both Citrus species were cultured on MS medium supplemented with (mg.liter $\left.{ }^{-1}\right) 0.25$ BAP, 0.5 NAA, and 0.5 IBA. These plantlets were successfully established in the soil. Chemical names used: naphthalene acetic acid (NAA), indole 3-butyric acid (IBA), and benzylamino purine (BAP).

Citrus reticulate $\mathrm{CV}$. Khasi mandarin and Citrus limon $\mathrm{CV}$. Assam lemon are the two most commercially important Citrus species of northeastern India. 'Khasi' mandarin is polyembtyonic, whereas 'Assam' lemon is monoembryonic. Both species are generally cross-pollinated. They are highly heterozygous, and zygotic embryos, even if produced by selfing, would differ from the maternal parents. In 'Khasi' mandarin, seedlings genetically identical to the maternal parents are derived from nucellar embtyos. However, nucellar and zygotic seedlings are difficult to distinguish by morphology at early growth stages. The methods available (several biochemical methods, including isozyme analysis) for distinguishing nucelksr from zygotic plants are either not sufficiently reliable or are laborious. They also require somewhat sophisticated laboratory equipment not usually available to nursery operators (Ashari et al., 1988; Furs and Reece, 1946; Pieringer and Edwards, 1965; Weinbaum et al., 1982). Further, plants grown from seeds exhibit extended juvenility. One method that can be used to overcome these problems is micropropagation of shoot tips derived from mature plants. This technique allows the establishment of true-to-type sexually mature plants for both species mentioned above. Although this can be achieved by conventional grafting, lack of suftlcient promising rootstock for 'Khasi' mandarin and 'Assam' lemon limits the scope of grafting.

Growing shoot tips (5 to $6 \mathrm{~cm}$ long) of 'Khasi' mandarin $(2 \mathrm{n}=18)$ and 'Assam' lemon $(2 \mathrm{n}=18)$ were collected from 5- to 6-year-old

Received for publication 30 Dec. 1992. Accepted for publication 28 June 1993. Financial assistance from the Dept. of Biotechnology, Govt. of India, New Delhi, is gratefully acknowledged. The cost of publishing this paper was defrayed in part by the payment of page charges. Under postal regulations, this paper therefore must be hereby marked advertisement solely to indicate this fact. plants from the orchard of the Assam Agricultural Univ., Jorhat. The expanded leaves were removed and washed thoroughly with a $1 \%$ solution of the detergent Teepol (Sigma, St. Louis) and then washed thoroughly with distilled water. Explants were surface-sterilized with $2 \%(\mathrm{w} / \mathrm{v})$ calcium hypochlorite solution
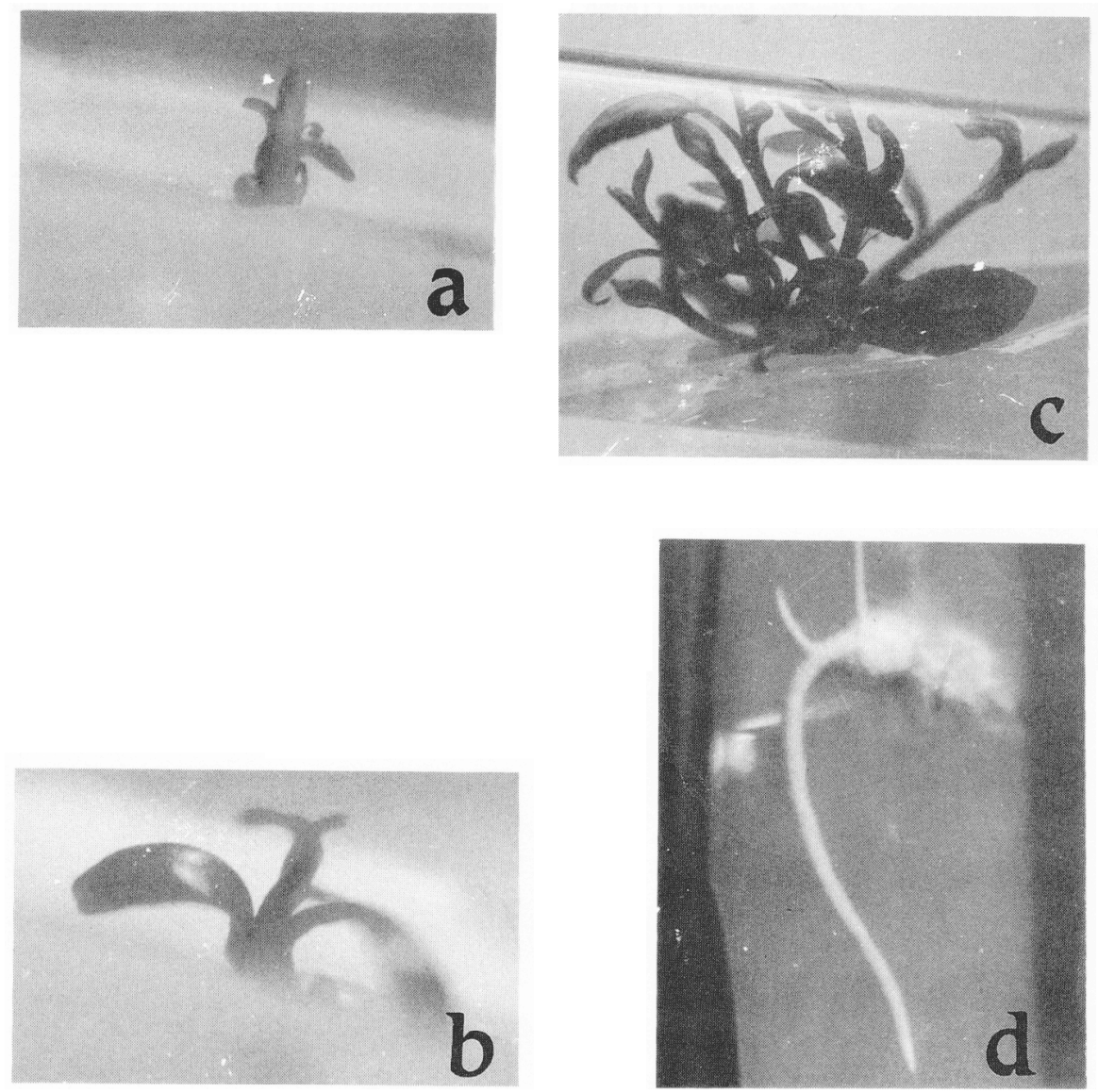

Fig. 1. (a) Citrus reticulate shoot tip ( 2 to $3 \mathrm{~mm}$ ) with two leaf primordia cultured in M2 medium. (b)
Regeneration of $C$. limon shoot tip in M2 medium after 17 days of culture. (e) Multiple shoots of $C$.

Fig. 1. (a) Citrus reticulate shoot tip ( 2 to $3 \mathrm{~mm}$ ) with two leaf primordia cultured in M2 medium. (b)
Regeneration of $C$. limon shoot tip in $\mathrm{M} 2$ medium after 17 days of culture. (e) Multiple shoots of $C$. reticulate developed after 7 weeks in M2 medium. (d) Root developed from single shoots of C. limon after 4 weeks in M5 medium. average length of shoots, and number of leaves per shoot were significantly higher in M2 medium compared to other media tested (Table 2, Fig. 1c). Altman and Goren (1974) reported that BAP and kinetin caused the development of multiple shoots in cultures of citrus lateral buds collected from a 40-year-old Shamouti

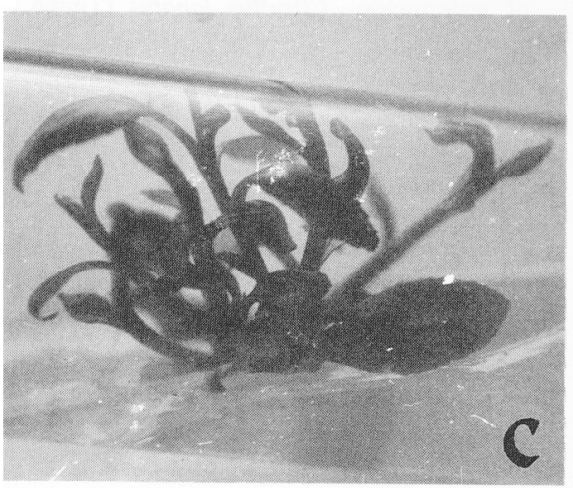

for $15 \mathrm{~min}$ and rinsed three times in sterile distilled water. Shoot tips ( 2 to $3 \mathrm{~mm}$ long) were isolated under aseptic conditions and inoculated into culture tubes $(25 \times 150 \mathrm{~mm})$ (Fig. 1a) containing $20 \mathrm{ml}$ of nutrient media. To study the effect of BAP, kinetin, and NAA on shoot proliferation, they were supplemented alone or in various combinations and concentrations in basal Murashige and Skoog (MS) (1962) medium with $0.8 \%$ agar (Himedia, India). Only those media (M1, M2, M3, and M4) where positive results were obtained are given (Table 1). The $\mathrm{pH}$ of the media was 5.8 before autoclaving. The culture tubes were maintained at $25 \sim 2 \mathrm{C}$ and 12-h light (3000 lx, Phillips TL 40W/54 fluorescent tubes)/12-h dark cycles. The data were tested by analysis of variance and least significant difference.

Applying BAP, kinetin, and NAA at 0.5 or $1 \mathrm{mg} \cdot$ liter $^{-1}$ did not allow shoot proliferation. A combination of $1.0 \mathrm{mg}$ BAP, $0.50 \mathrm{mg}$ kinetin, and $0.50 \mathrm{mgNAA} / \mathrm{liter}$ (M2 medium) gave the highest percentage of shoot proliferation in both species (Table 2, Fig. lb). After 7 weeks of culture, the number of multiple shoots, 
Table 1. Composition (in mg.liter ${ }^{-1}$ ) of various modified Murashige and Skoog media tested for shoot-tip culture of Citrus reticulata and C. limon.

\begin{tabular}{lccccccc}
\hline \hline $\begin{array}{l}\text { Growth } \\
\text { regulators }\end{array}$ & \multicolumn{7}{c}{ Medium } \\
\cline { 3 - 8 } & M0 & M1 & M2 & M3 & M4 & M5 & M6 \\
\hline & & \multicolumn{7}{c}{$\left(m g\right.$ liter $\left.^{-1}\right)$} \\
BAP & 0.0 & 0.5 & 1.0 & 0.5 & 1.0 & 0.25 & 0.25 \\
Kinetin & 0.0 & 0.5 & 0.5 & 1.0 & 1.0 & --- & -- \\
NAA & 0.0 & 0.5 & 0.5 & 0.5 & 0.5 & 0.5 & 1.00 \\
IBA & 0.0 & $-\cdots$ & $-\cdots$ & --- & -- & 0.5 & 1.00 \\
\hline
\end{tabular}

Table 2. Shoot-tip culture of Citrus reticulata and C. limon on modified MS media. ${ }^{2}$

\begin{tabular}{|c|c|c|c|c|c|c|c|}
\hline \multirow[b]{3}{*}{ Medium } & \multirow{3}{*}{$\begin{array}{c}\text { Cultures with } \\
\text { multiple shoots } \\
\text { (\%) }\end{array}$} & & & \multicolumn{4}{|c|}{ Characteristics after 7 weeks } \\
\hline & & Time ela & on (days) & \multirow{2}{*}{$\begin{array}{c}\text { Shoots } \\
\text { developed/explant } \\
\text { (no. } \pm \text { SE) }\end{array}$} & \multirow{2}{*}{$\begin{array}{c}\text { Shoot } \\
\text { length/culture } \\
(\mathrm{cm} \pm \mathrm{SE})\end{array}$} & & \multirow{2}{*}{$\begin{array}{c}\text { Leaves } \\
\text { developed/shoot } \\
\text { (no. } \pm \mathrm{SE} \text { ) }\end{array}$} \\
\hline & & Shoot & Leaf & & & & \\
\hline \multicolumn{8}{|c|}{ C. reticulata } \\
\hline M0 & $00.0^{\mathrm{x}}$ & --- & -- & $\therefore$ & --- & \multirow{6}{*}{$\cdots$} & --- \\
\hline M1 & 30.0 & 21 & 24 & $2.3 \pm 0.17$ & $0.95 \pm 0.14$ & & $1.25 \pm 0.18$ \\
\hline M2 & 70.0 & 17 & 19 & $6.1 \pm 0.11$ & $2.60 \pm 0.09$ & & $2.40 \pm 0.12$ \\
\hline M3 & 52.5 & 19 & 21 & $3.4 \pm 0.13$ & $1.20 \pm 0.11$ & & $1.35 \pm 0.14$ \\
\hline M4 & 50.0 & 19 & 21 & $3.2 \pm 0.13$ & $1.15 \pm 0.11$ & & $1.40 \pm 0.14$ \\
\hline $\operatorname{LSD}_{0.05}$ & & & & 0.690 & 0.587 & & 0.410 \\
\hline \multicolumn{8}{|l|}{ C. limon } \\
\hline MO & 00.0 & --- & --- & -- & $-\quad---$ & & --- \\
\hline M1 & 40.0 & 22 & 24 & $2.4 \pm 0.17$ & $1.00 \pm 0.12$ & & $1.30 \pm 0.18$ \\
\hline M2 & 75.0 & 18 & 20 & $6.7 \pm 0.11$ & $2.50 \pm 0.09$ & & $2.60 \pm 0.12$ \\
\hline M3 & 50.0 & 20 & 22 & $2.5 \pm 0.13$ & $1.30 \pm 0.11$ & & $1.30 \pm 0.13$ \\
\hline M4 & 30.0 & 19 & 21 & $3.3 \pm 0.13$ & $1.20 \pm 0.11$ & & $1.35 \pm 0.14$ \\
\hline $\mathrm{LSD}_{0.05}$ & & & & 0.610 & 0.593 & & 0.497 \\
\hline
\end{tabular}

${ }^{2}$ There were 40 shoot tips per medium.

${ }^{y}$ Values refer to the percentage of explants that produced multiple shoots.

'Zero values indicate absent; of multiple shoots.

orange (C. sinensis) tree. Barlass and Skene (1982) reported development of adventitious buds from shoot apex collected from mature plants of $C$. reticulate $\mathrm{CV}$. Cleopatra mandarin in MS medium with BAP $\left(0.50 \mathrm{mg} \cdot \mathrm{liter}^{-1}\right)$. Pasqual and Audo (1989) reported axillary bud multiplication (juvenile explants) of Poncirus trifoliata in MS medium with $1 \mathrm{mg}$ NAA and 2 mg BAP/liter. Thus, the combination of BAP, NAA, and kinetin appeared to be essential for multiple-shoot formation in different Citrus species.

For root induction, several combinations and concentrations of BAP, NAA, and IBA were tried, but only those media (M5 and M6) that elicited favorable root induction are shown (Table 1). Root induction was possible only when IRA was added to the medium. Roots were initiated and developed when excised single shoots were transferred to M5 and M6 media (Table 3). A combination of $0.50 \mathrm{mg}$ NAA, $0.50 \mathrm{mg}$ IBA, and $0.25 \mathrm{mg} \mathrm{BAP} /$ liter
(M5 medium) was best for root development in both Citrus species.

Root initiation generally took place within 17 to 18 days of inoculation on M5 medium. The average number and length of roots were found to be significantly higher in M5 medium for both Citrus species after 4 weeks of culture (Table 3, Fig. id). Root initiation usually occurred near the cut surface of the shoot explant's basal ends. Nel ( 1987) reported root development from shoot meristems of in vitrogrown seedlings of Citrus species after 2 months in half-strength Murashige and Tucker (1969) medium supplemented with NAA only. Starrantino and Caruso ( 1988) reported rooting from excised shoots of citranges and trifoliate orange (Poncirus triloliata) cv. Flying Dragon on MS medium without cytokinin or IBA but with NAA ( $1 \mathrm{mg} \cdot$ liter $\left.^{-1}\right)$. However, in our investigation, a combination of NAA, IBA, and BAP was found to be essential for root development. Rooted shoots of both Citrus

Table 3. Rooting of Citrus reticulata and $C$. limon shoots on modified MS media. ${ }^{2}$

\begin{tabular}{lcccc}
\hline \hline & $\begin{array}{c}\text { Shoot explants } \\
\text { formed roots } \\
\text { Medium }\end{array}$ & $\begin{array}{c}\text { Avg days to } \\
\text { root initiation }\end{array}$ & $\begin{array}{c}\text { Characteristics } \\
\text { after 4 weeks }\end{array}$ \\
$\begin{array}{l}\text { C. reticulata } \\
\text { M5 }\end{array}$ & 70 & 18 & $\begin{array}{c}\text { Roots/explant } \\
\text { (no. } \pm \text { SE) }\end{array}$ & $\begin{array}{c}\text { Length of roots } \\
\text { (cm } \pm \text { SE) }\end{array}$ \\
M6 & 40 & 21 & $4.3 \pm 0.09$ & $1.6 \pm 0.64$ \\
LSD 0.05 & & & $2.4 \pm 0.13$ & $0.7 \pm 0.08$ \\
C. limon & 80 & 17 & 0.688 & 0.426 \\
M5 & 50 & 22 & $4.9 \pm 0.09$ & $1.65 \pm 0.03$ \\
M6 & & & $2.6 \pm 0.13$ & $0.80 \pm 0.04$ \\
LSD $_{0.05}$ & & & 0.594 & 0.253 \\
\hline
\end{tabular}

${ }^{2}$ There were 40 shoots per treatment.

'Vatues refer to the percentage of explants that produced roots. species were transferred to MS inorganic + $1 \%$ agar (Himedia, India) after 5 weeks. After 8 weeks, in vitro-grown plantlets were thoroughly washed with tap water to remove agar from the roots, which were then soaked in $0.2 \%$ Bavistin (BASF, India), a fungicide, for 5 to $10 \mathrm{~min}$. The plantlets were potted in a sterilized mixture of 1 sand: 1 soil. They were initially irrigated with half-strength MS solution for 1 week, and subsequently with water. They were acclimatized at $27 \pm 2 \mathrm{C}$ with a 16 $\mathrm{h}$ photoperiod for 3 to 4 weeks. Polyethylene covers were used to ensure high humidity around plants. About $60 \%$ of the plantlets were established in soil. Established plantlets were then transplanted to the field and watered regularly. Based on morphological characters such as thorniness, growth habit, internode length and leaf size, the established plants did not appear to be juvenile. However, the final assessment of maturity can be made only when the plants reach the flowering stage.

In conclusion, in most reports on Citrus micropropagation, juvenile explants derived from seedling tissues have been used. We have been able to micropropagate explants derived from mature plants of two Citrus species where this has not been previously accomplished.

\section{Literature Cited}

Altman, A. and R. Goren. 1974. Growth and dormancy cycle in citrus bud culture and their hormonal control. Physiol. P1ant. 30:240-245. Ashari, S., D. Aspinall, and M. Sedgley. 1988. Discrimination of zygotic and nucellar seedlings of five polyembryonic citrus rootstock by isozyme analysis and seedling morphology. J. Hort. Sci. 63:695-703. 
Barlass, M. and K.G.M. Skene. 1982. In vitro plantlet formation from Citrus species and hybrids. Sci. Hort. 17:333-314.

Furr, J.R. and P.C. Reece. 1946. Identification of hybrids and nucellar citrus seedlings by a modification of the rootstock colour test. J. Amer. Soc. Hort. Sci. 46:141-146.

Murashige, T. and F. Skoog. 1962. A revised medium for rapid growth and bioassay with tobacco tissue culture. Physiol. Plant. 15:473497.

Murashige, T. and D.P.F. Tucker. 1969. Growth factor requirements of citrus tissue culture, $p$. 1155-1161. In: H.D. Chapman (ed.). Proc. 1st Intl. Citrus Symp. vol. III. Univ. of California, Riverside.

Nel, M. 1987. In vitro culture of citrus meristems. Info. Bul. Citrus and Subtropical Fruit Res. Inst., South Africa. 175:9.

Pasqual, M. and A. Audo. 1989. Micropropagation of trifoliata through axillary buds in in vitro culture. Pesquisa Agropecuaria Brasileira. 24:217-220.

Pieringer, A.P. and G.J. Edwards. 1965. Identifica- tion of nucellar and zygotic seedlings by infrared spectroscopy. J. Amer. Soc. Hort. Sci. 86:226-234.

Starrantino. A. and A. Caruso. 1988. The in vitro culture technique for the micropropagation of citranges and trifoliate orange cv. Flying Dragon. Instituto sperimentale perl' Agrumicoltura, Italy. 17-18:259-271.

Weinbaum, S.A., E. Cohen, and P. Spiegel-Roy. 1982. Rapid screening of 'Satsuma' mandarin progeny to distinguish nucellar and zygotic seedlings. HortScience 17:239-240. 